\title{
A research on social media usage of accommodation companies in Rize
}

\author{
Gülsün Yıldırım, Eren Erkılıç²
}

\begin{abstract}
Through the development of technology, widespread use of the Internet and smart phones, bilateral communication between consumers and consumers, consumers and businesses and other businesses has become possible. With the increasing information sharing in the tourism sector and the increasing role of social media on this issue, tourism enterprises have to be active in social media. In addition to traditional marketing methods, the importance given to social media marketing is increasing day by day. Thus, in this study, social media use cases of hotels in Rize province, which is one of Turkey's popular tourist attractions and its effect on hotel occupancy rates were examined. First of all, web sites of the hotels were examined and their status in social media accounts was determined. Afterwards, if any, shared photographs were analyzed through social media accounts and their interaction with visitors was evaluated. Then, the effects of social media usage of hotels with social media accounts on hotel occupancy were tried to be revealed. In this study qualitative research method was chosen and interview technique was used to collect data. At the end of the study, results revealed that factors such as a lot of photo sharing in instagram accounts of hotels, giving more attention to the sharing of visitor-themed photos within the instagram account are effective on increasing the number of followers and this was resulted in an increase in the Hotel demand.
\end{abstract}

Keywords: Tourism, Social Media Marketing, Content Analysis

\section{Rize'deki konaklama işletmelerinin sosyal medya kullanımı üzerine bir araştırma}

\section{$\ddot{O} z$}

Teknolojinin gelişmesi, internet kullanımının yaygınlaşması ve akıllı telefonlar aracılığıyla tüketicilerle tüketiciler, tüketicilerle işletmeler ve işletmeler ile diğer işletmeler arasında çift taraflı iletişim mümkün hale gelmiştir. Turizm sektöründe artan bilgi paylaşımı ve sosyal medyanın bu konuda artan rolü ile turizm işletmelerinin sosyal medyada etkin olmaları bir zorunluluk haline gelmiştir. Geleneksel pazarlama yöntemlerinin yanı sıra sosyal medya pazarlamasına verilen önem gün geçtikçe artmaktadır. Buradan hareketle bu çalışmada, Türkiye'nin gözde turistik merkezlerinden biri olan Rize ilindeki konaklama işletmelerinin sosyal medya kullanım durumları ve bunun otel doluluk oranlarına etkisi incelenmiştir. Öncelikle konaklama işletmelerinin web sayfaları incelenmiş, web sitelerinde sosyal medya hesaplarına yer verme durumları belirlenmiştir. Sonrasında ĕger varsa, sosyal medya hesapları üzerinden paylaşılan fotoğraflar incelenmiş ve ziyaretçilerle etkileşim durumları değerlendirilmiştir. Daha sonra, sosyal medya hesabı olan otellerin sosyal medya kullanımlarının otel doluluklarına etkisi ortaya çıkarılmaya çalışılmıştır. Nitel araştırma yöntemi kullanılan bu çalışmada verilerin toplanmasında görüşme tekniğinden yararlanılmıştır. Çalışma sonunda, konaklama tesislerinin instagram hesaplarında fotoğraf paylaşımının çok olması, konaklama tesisi içerisindeki ziyaretçi temalı fotoğrafların paylaşımına daha fazla önem verilmesi gibi unsurların takipçi sayısı üzerinde etkili olduğu, bunun da otele olan talebe yansıdığı sonucu çıkmıştır.

Anahtar sözcükler: Turizm, Sosyal Medya Pazarlaması, İçerik Analizi

$\begin{array}{ll}\text { Geliş Tarihi } & : 10.06 .2019 \\ \text { Kabul Tarihi } & : 13.10 .2019\end{array}$

Alıntı için: Yıldırım, G., Erkılıç, E. (2019). Rize'deki konaklama işletmelerinin sosyal medya kullanımı üzerine bir araştırma. Journal of Tourism Theory and Research, 5(3), 380-395.

\footnotetext{
${ }^{1}$ Asst. Prof. Dr., Ardeşen Turizm Fakültesi, Recep Tayyip Erdogan Üniversitesi/Rize/Türkiye gulsun.yildirim@erdogan.edu.tr ${ }^{2}$ Asst. Prof. Dr., Ardeşen Turizm Fakültesi, Recep Tayyip Erdogan Üniversitesi/Rize/Türkiye, eren.erkilic@erdogan.edu.tr 


\section{Giriş}

Teknolojinin gelişimi ve internet kullanımının yaygınlaşması ile birlikte turistlerin ve turistlere hizmet sunan işletmelerin sosyal medya üzerinden fotoğraf ve içerik paylaşım sayıları gün geçtikçe artmaktadır. Hem turistler açısından hem de turizm işletmeleri açısından sosyal medya üzerinden paylaşılan fotoğraflar ve alınan veya sunulan hizmetlerle ilgili paylaşımlar gün geçtikçe önem kazanmaktadır. Sosyal medya ve turizm ile ilgili alan yazında birçok çalışma yapılmıştır (Knights ve Wilmott, 2007; Lee, 2012; Yahya, Azizam ve Mazlan, 2014; Carr ve Maier, 2013; Rishi ve Gaur, 2012; Zeng, 2013). Bu çalışmaların bir kısmı turistlerin gittikleri yerler ve aldıkları hizmetlerle ilgili değerlendirmelerin analizi şeklindedir (Eren \& Çelik, 2017; Corbau, Benedetto, Congiatu, Simeoni \&Carboni, 2019; Shao, Zhang \& Li, 2017, Zeng, 2013). Bazı çalışmalar ise sosyal medyanın işletmeler açısından alternatif pazarlama stratejisi bağlamında önemine değinmiş̧tir (Werthner ve Klein's, 1999; Fesenmaier, Wöber ve Werthner, 2006). Konu ile ilgili yapılan çalışmalar genel olarak değerlendirildiğinde Türkiye'de sosyal medyada paylaşılan fotoğrafların analizi üzerine sınırlı sayıda çalışma yapıldığı gözlemlenmiştir.

Son y1llarda teknolojideki gelişmeler, internet kullanımının yaygınlaşması ve mobil teknolojilerin yaygın olarak kullanılması, seyahate katılanların deneyimleri ile ilgili oldukça fazla verinin ortaya çıkmasına neden olmuştur. Turizmde sosyal medyanın stratejik pazarlama aracı olarak öneminin fark edilmesinden sonra turizmde bilgi teknolojileri ve e-tourism üzerine birçok çalışma yapılmıştır (Ukpabi ve Karjaluoto,2017; Sheldon, 1997; Werthner ve Klein's, 1999; Fesenmaier, Wöber ve Werthner, 2006). DiStaso ve McCorkindale (2012)'nin yapmış oldukları çalışmada sosyal medya stratejileri geliştirmeyen örgütlerin müşterilerinin işletme ile iletişimlerinin, bağl1lıklarının ve işletmeye yönelik güvenlerinin düştüğü görülmüştür.

Turizm faaliyetine katılan kişilerin oluşturduğu sosyal medya verileri; yapılan yorumlar ve paylaşılan fotoğraflar şeklinde olmaktadır. Sosyal medya hesabı üzerinden paylaşılan fotoğraflarda coğrafi etiketleme yapılabilirken aynı zamanda kişilerin tatil deneyimlerine ilişkin detaylı bilgilere de yer verilmektedir. İnsanların tatil deneyimlerini paylaştıkları en popüler online kaynaklar Instagram, Flickr ve Facebook vb. şeklindedir (Vu vd., 2015 ). Bu sosyal medya araçlarının yaygınlaşmas1, internetin sadece yayınların yapıldığı bir platformdan öte, katılımın sağlandığ ların kurulduğu bir platform olmasina vesile olmuştur (Xiang, 2018). Ayrıca, sosyal medya uygulamalarından paylaşılan fotoğraf, yorum ve videolar müşterilerin satın alma davranışına doğrudan etki etmektedir (Iacovou, 2016).

Teknolojinin gelişmesi, internetin yaygınlaşmas1, mobil teknolojilerin (Van House, 2011) ve sosyal medya kullanımının artmasına bağlı olarak, sosyal medya üzerinden paylaşılan fotoğraflar ve içeriklerin tüketici tercihlerinde ve işletmelerin pazarlanmasında önemli bir faktör haline geldiği göz önüne alınarak, bu çalışmada Türkiye'nin Doğu Karadeniz Bölgesinde önemli bir turizm destinasyonu olan Rize ilindeki konaklama işletmelerinin sosyal medya kullanım durumları ve bunun otel doluluk oranlarına etkisi araştırılmıştır. $\mathrm{Bu}$ çalışmada öncelikle Rize ilindeki konaklama işletmelerinin web sayfaları, ardından instagram hesapları incelenmiştir. Konaklama tesislerinin instagramdaki profilleri incelenmiş ve tesislerin instagramda paylaştıkları fotoğrafların beğeni ve yorum sayıları, kapsadıkları içeriklere ilişkin temalar ortaya çıkarılmıştır. Tüketicilerin satın alma kararı aşamasında sosyal medyanın etkin rolünden yola çıkarak Rize ilindeki konaklama işletmelerin sosyal medya kullanım durumlarının tespit edilmesi ve sosyal medya kullanımının otel doluluklarına olan etkisinin ortaya çıkarılması Rize'deki işletmeler açısından önem arz etmektedir. Ayrıca bu araştırmanın, işletmelerin sosyal medyayı pazarlama aracı olarak kullanım durumlarının ortaya çıkarılmasında fayda sağlayacağı düşünülmektedir. Alan yazında turizm ve sosyal medya, paylaşılan fotoğraflar ve bunların satışlara etkisine ilişkin her ne kadar dünyada fazla çalışma yapılmış olsa da, Türkiye'de bu konuda çok fazla çalışma yapılmamıştır. Dolayısı ile bu çalışmanın alan yazına katkı sunacağı düşünülmektedir. 


\section{Literatür}

Görsel veri olarak fotoğrafların bilimsel araştırmalarda kullanımına yönelik bazı tartışmalar (Balomenou ve Garrod, 2019) olsa da teknolojinin gelişmesi, internetin yaygınlaşması ve sosyal medyanın dünya genelinde kullanımının artması (Moore, 2017) ile sosyal medyadaki paylaşımların bilimsel araştırmalarda yaygın olarak kullanılmasını da kaçınılmaz hale gelmiştir.

Sosyal bilimler alanındaki araştırmalarda, kelimelere oranla görsellerin daha önemli olduğu ileri sürülmüştür (Khoo- Lattimore ve Prideaux, 2013. Akıllı telefonların yaygınlaşması ile kullanıcılar bilgiye çabuk bir şekilde ulaşıp aynı hızla bilgiyi yayabilmekte ve sosyal medya siteleri üzerinden çevrimiçi diyaloglara katılabilmekte (Barwise ve Strong, 2002; Knackmuhs, 2011) ve bu sayede işletmelerle iki taraflı iletişime geçebilmektedir (Okazaki ve Taylor, 2013:18; Aluri, 2012). Video ve fotoğraf paylaşmaya imkân veren teknolojilerin yaygınlaşması ile birlikte bu çift taraflı iletişim daha da zenginleşmektedir (Iacovou, 2016). En fazla fotoğraf ve video paylaşım platformlarından biri olan instagram'a, 2016 y1lında, günde 80 milyon fotoğraf yüklenmiştir (Diehl vd., 2016). 2017 yılına gelindiğinde günlük instagramda paylaşılan fotoğraf sayısı 21,9 milyara ulaşmıștır (Balomenou ve Garrod, 2019).

Ayrica insanların, tatillerini planlama ve tatil kararlarını verme aşamasında sosyal medyadaki paylaşımlardan etkilendiği de görülmüş̧ür (Knights ve Wilmott, 2007). Tatile çıkan insanların paylaştıkları fotoğraflar ve bazı platformlarda yaptıkları yorumların önemi de çok geç olmadan anlaşılmıştır (Lee, 2012; Yahya, Azizam ve Mazlan, 2014). Carr ve Maier (2013)'e göre satın alma kararı sırasında, müşteriler diğer müşteri yorumlarına oldukça güvenmektedir. Turistler diğer turistlerin yaptığı paylaşımlara ve yorumlara, turizm işletmeleri tarafından sosyal medyada yapılan reklam mesajlarına oranla daha fazla güvenmektedir (Barreda ve Bilgihan, 2013).

Turizm işletmelerinin kendi web siteleri haricinde instagram, facebook gibi platformlarda var olmalarının birçok avantajı bulunmaktadır. Web siteleri tek taraflı iletişimle sınırlı kalırken bu platformlar iki taraflı iletişim sağlamaktadır (Nyakabwa, 2017). Bu platformlar aracılığıyla işletme ile ilgili yenilikler hakkında bilgiler kolaylıkla yayılabilmektedir (Di Pietro vd., 2012). İşletmelerin kendilerinin ve turistik ürünlerinin tanıtımının sağlanması (Rishi ve Gaur, 2012) ve potansiyel müşterilerin talepleri doğrultusunda ürün alternatiflerinin sunulması (Safko, 2013) bu avantajlar arasındadır. Al-Badi ve Al-Qayoudhi (2014)'e göre işletmelerin facebook gibi platformlarda sayfalarının olması bu işletmelerin ürünlerini pazarlayacakları potansiyel müşterileri bulmak için ekstra harcama yapma gereksinimlerini ortadan kaldırmaktadır. $\mathrm{Bu}$ sayede, pazarlama kampanyalarına daha az harcama yapılacağından dolayı işletmelerin gelirleri de arttıracaktır. Buna karşın, Zeng (2013)'in sosyal medyanın otel rezervasyonlarına yönelik etkisini ölçtügü çalışmada, sosyal medya ve turizm sektörü arasında önemli bir ekonomik ilişki bulunmamıştır.

İşletme pazarlamacıları pazarda işletmeyi hedeflenen konuma konumlandırmak için, işletme imajını oluşturmak veya güçlendirmek için birden çok sosyal medya uygulaması kullanmalıdır (Iacovou, 2016: 32). Pazarlamacılar artık geleneksel pazarlamanın yanı sıra sosyal medya pazarlamasının da bütünleşik olarak kullanılması gerektiğinin yeni yeni farkına varmaktadırlar (Weber, 2013). Bazı turizm işletmecileri sosyal medya kullanımının ve o sitelerde yapılan paylaşımların önemini göz ardı etseler de bazı işletmeciler de sosyal medyanın ne kadar önemli olduğunun farkındadır ve bu konuya oldukça önem vermektedir (Iacovou, 2016).

Tüm bu hususlar doğrultusunda da alan yazında turizm ve sosyal medya ilișkisine yönelik yapılan bilimsel çalışmaların sayısı da gün geçtikçe artmıştır. Turizm ve sosyal medya bağlamında yapılan çalışmalarda verilerin sosyal medya hesapları üzerinden yapılan yorumlardan mı yoksa sosyal medya hesaplarında paylaşılan fotoğraflardan $\mathrm{m} 1$ elde edildiğine yönelik yapılan bazı çalışmalar Tablo 1'de listelenmiştir.

Her ne kadar bilimsel çalışmalarda sosyal medya hesapları üzerinden insanların deneyimlerine ilişkin yazdıkları metinler ağırlıklı olarak incelenmekte olsa da, Balomenou ve Garrod 
(2019:201)'e göre görsel veri oldukça değerlidir. Çünkü görsel veri özellikle turizm araştırmalarında iki önemli bilişsel boşluk arasında köprü kurmada yardımcı olmaktadır. Bunlar; kelimelerle görseller arasındaki boşluk ve araştırmacılar ile katılımcılar arasındaki boşluktur.

Tablo 1. Turizm ve sosyal medya bağlamında incelenen veriler çerçevesinde yapılan çalışmalar

\begin{tabular}{|l|l|}
\hline Metin Analizi & $\begin{array}{l}\text { Eren \& Çelik, 2017; Corbau, Benedetto, Congiatu, Simeoni \&Carboni, 2019; Shao, Zhang } \\
\text { \& Li, 2017; Erkılıç, Kılıç, Pelit \& K1lıç 2016; Gedikoglu, 2018; Muckensturm, 2013; } \\
\text { Leung, 2012; Chung, Chung \& Nam, 2017; Smallwood, Beckley \& Moore, 2012; Erkılıç, } \\
\text { Güçer, Pelit \& Aytekin, 2016; Erkılıç\&Yıldırım, 2019 }\end{array}$ \\
\hline $\begin{array}{l}\text { Feng \& Li, 2018; Garcia- Palomares, Gutierrez \& Minguez, 2015; Giglio, Bertacchini, } \\
\text { Bilotta \& Pantano, 2019; Jiang, Yin, Wang \& Yu, 2013; Balomenou \& Garrod, 2019; Nik- } \\
\text { joo \& Bakhshi, 2019; Vu vd., 2015; García-Palomares, Gutiérrez \& Mínguez, 2015; Ken- } \\
\text { nedy, Naaman, Ahern, Nair \& Rattenbury, 2007; Kisilevich, Keim \& Rokach, 2010; Ku- } \\
\text { rashima, Iwata, Irie \& Fujimura, 2013; Li, 2013; Snavely, Seitz \& Szeliski, 2008; Yang, } \\
\text { Wu, Liu \& Kang, 2017; Yuan \& Medel, 2016; Zheng, Zha \& Chua, 2012; Bayram vd., } \\
\text { 2016 }\end{array}$ \\
\hline $\begin{array}{l}\text { Metin ve Fotoğ- } \\
\text { raf Analizi }\end{array}$ & $\begin{array}{l}\text { Li, Huang \& Christianson, 2016; Ma, Xiang, Du \& Fan, 2018; Lee Rosen, 2017; Marek, } \\
\text { 2015; Hazarhun \& Devrim Yılmaz, 2018 }\end{array}$ \\
\hline
\end{tabular}

Seyahat edenlerin ihtiyaçlarının, memnuniyet durumlarının ve satın alma niyetlerinin bilinmesi konaklama işletmelerinin başarısı için önemlidir. İnternet kullanıcıları için sosyal medyanın etkisi göz önüne alındığında konaklama işletmeleri için sosyal medyanın rolünün bilinmesi önemlidir (Aluri, 2012). Konaklama işletmelerinin web sitelerinde sosyal medya hesaplarına yer vermesinin seyahat edenlerin davranışlanına etki edip etmediği araştırma konusu olmuştur (McKay, 2010). McCarthy, Stock ve Verma (2010) sosyal medyanın tüketicilerin kalınacak otele karar verme aşamasında etkili olduğunu ileri sürmüştür. Buradan hareketle bu çalışmada işletmelerin web sitelerinde sosyal medya hesaplarına yer verme durumları, sosyal medya hesapları üzerinden yaptıkları paylaşımlar, bu paylaşımların etkileşim durumları ve otel doluluk oranlarına etkisi incelenmiştir.

\section{Yöntem}

Sosyal medya kullanımının artmasına bağlı olarak, sosyal medya üzerinden paylaşılan fotoğraflar ve içeriklerin tüketici tercihlerinde ve işletmelerin pazarlanmasında önemli bir faktör haline geldiği göz önüne alınarak, bu çalışmada Türkiye'nin Doğu Karadeniz Bölgesinde önemli bir turizm destinasyonu olan Rize ilindeki Kültür ve Turizm Bakanlığı İşletme Belgeli konaklama işletmelerinin sosyal medya kullanım durumları ve otel doluluk oranlarına etkisi araştırılmıștır. Bu bağlamda araştırmanın ana sorunsalı şu şekildedir:

- Türkiye'nin Doğu Karadeniz Bölgesinde önemli bir turizm destinasyonu olan Rize ilindeki konaklama işletmelerinin sosyal medya kullanım durumları nasıldır ve sosyal medya kullanımının otel doluluk oranlarına etkisi nasıldır?

$\mathrm{Bu}$ ana sorunsal kapsamında araştırmanın iki alt sorunsalı şu şekildedir:

- Rize ilindeki konaklama işletmecilerinin sosyal medya kullanımına yönelik düşünceleri nelerdir?

- Rize ilindeki konaklama işletmelerinin sosyal medyada ziyaretçilerle etkileşim düzeyleri nasildır?

- Etkileşim düzeyi yüksek olan konaklama işletmelerinin düşük olanlara göre paylaşım durumları arasındaki farklılıklar nelerdir?

- Etkileşim düzeyi düşük olan konaklama işletmelerine kıyasla etkileşim düzeyi yüksek olan işletmelere olan talep nasıldır?

$\mathrm{Bu}$ çalışmada öncelikle Rize ilindeki konaklama işletmelerinin web sayfaları ardından instagram hesapları incelenmiştir. Farklı sosyal medya türlerinden özellikle instagramın seçilmesinin nedeni, insanların görsel verilere önem vermesi (Ba- 
lomenou ve Garrod, 2019:201) ve en fazla fotoğraf ve video paylaşım platformlarından birinin instagram (Diehl vd., 2016) olmasıdır.

Konaklama tesislerinin instagramdaki profilleri incelenmiş, tesislerin instagramda paylaştıkları fotoğrafların beğeni ve yorum sayıları belirlenmiş ve kapsadıkları içeriklere ilişkin temalar ortaya çıkarılmıştır. Çalışmanın ikinci kısmında instagram hesabı olan konaklama işletmesi temsilcileri ile sosyal medya kullanımına yönelik ve sosyal medya kullanımının talebi etkileyip etkilemediğine dair düşüncelerini ortaya çıkarmak için görüşmeler yapılmıştır.

Rize ilinde Kültür ve Turizm Bakanlığ 1 İşletme Belgeli toplam 13 tesis bulunmaktadır. Araştırmanın ilk kısmında tüm tesislerin web siteleri ve instagram kullanım durumları incelenmiştir. Araştırmanın ikinci kısmında instagram hesabı olan otel temsilcileri ile görüşülmüştür. Bu kısımda, instagram hesabının kullanımının otel doluluk oranlarını etkileyip etkilemediği araştırıldığından Instagram hesabı olmayan otellerin temsilcileri ile görüşülmemiştir.

Tablo 2. Rize'deki Kültür ve Turizm Bakanlığ 1 İşletme Belgeli Konaklama İşletmeleri

\begin{tabular}{|c|c|c|c|c|}
\hline & $\begin{array}{c}\text { Tesisin } \\
\text { Ad1 }\end{array}$ & Sinıfi & $\begin{array}{c}\text { Oda Sa- } \\
\text { y1s1 }\end{array}$ & $\begin{array}{c}\text { Yatak } \\
\text { Say1s1 }\end{array}$ \\
\hline 1 & $\mathrm{X} 1$ & $* * * *$ & 290 & 602 \\
\hline 2 & $\mathrm{X} 2$ & $* * * *$ & 114 & 232 \\
\hline 3 & $\mathrm{X} 3$ & $* * *$ & 89 & 178 \\
\hline 4 & $\mathrm{X} 4$ & $* * *$ & 25 & 50 \\
\hline 5 & $\mathrm{X} 5$ & $* * *$ & 55 & 110 \\
\hline 6 & $\mathrm{X} 6$ & $* * *$ & 42 & 86 \\
\hline 7 & $\mathrm{X} 7$ & $* * *$ & 26 & 52 \\
\hline 8 & $\mathrm{X} 8$ & $* * *$ & 25 & 50 \\
\hline 9 & $\mathrm{X} 9$ & $* *$ & 26 & 52 \\
\hline 10 & $\mathrm{X} 10$ & $* *$ & 29 & 58 \\
\hline 11 & $\mathrm{X} 11$ & $* *$ & 26 & 52 \\
\hline 12 & $\mathrm{X} 12$ & Özel & 7 & 14 \\
\hline 13 & $\mathrm{X} 13$ & $\begin{array}{c}\text { Butik } \\
\text { Otel }\end{array}$ & 60 & 120 \\
\hline
\end{tabular}

Kaynak: İl Kültür ve Turizm Müdürlüğü, http://www.rizekulturturizm.gov.tr (2018)

Araştırmada Rize'de faaliyet gösteren konaklama tesislerinin işletmelerini temsil eden instagram hesapları üzerinde yer verdikleri fotoğrafların içeriklerini incelemek, sosyal medya kullanımına yönelik düşüncelerini belirlemek ve sosyal medya kullanımının otel doluluklarına etkisini ortaya ç1karmak için nitel araştırma yöntemlerinden faydalanılmıştır. Nitel araştırma "İnsanın kendi sınırlarını çözmek ve kendi çabasıyla biçimlendirdiği toplumsal sistemlerin derinliklerini keşfetmek üzere geliștirdiği bilgi üretme yollarından birisi" olarak tanımlanmaktadır (Özdemir, 2010, s. 326).

Araştırmada bu yöntem neticesinde veri analizi olarak "içerik analizi” kullanılmıştır. İçerik analizi "işaretlerin sinıflanması ve bu işaretlerin hangi yargıları içerdiğini ortaya koymak için açıkça formüle edilmiş kurallar ışığında araştırmacının ortaya koyduğu yargiların bilimsel rapor olarak değerlendirilmesini sağlar" (Janis 1949: 425) şeklinde tanımlanmaktadır. Bu çerçevede araştırmanın ilk kısmında Rize'de faaliyet gösteren Kültür ve Turizm Bakanlığı İşletme Belgeli tesislerin tamamı araştırmaya dâhil edilmiştir. Rize İl Kültür ve Turizm Müdürlüğü verilerine göre (2018) Rize'de 13 adet Kültür ve Turizm Bakanlığı İşletme Belgeli konaklama tesisi bulunmakta olup (Tablo 2); tesislerin ikisi 5 yıldızlı, altısı 3 yıldızlı, üçü 2 yıldızlı, biri özel ve biri butik otel sınıfinda yer almaktadır. Araştırmanın ikinci kısmında ise sosyal medya kullanımının otel doluluklarına etkisini belirlemek için sosyal medya hesabı olan 9 otel işletmesi ile görüşülmüştür.

Araştırma kapsamında yer alan konaklama işletmelerinin web sayfaları incelenerek ilgili sayfalarda instagram hesabının olup olmadığı belirlenmeye çalışılmıştır. Araştırmanın devam eden kısmında 01.01.2019 tarihinde ilgili konaklama işletmelerinin instagram hesaplarındaki son 15 fotoğraf içerik analizi ile incelenmiştir. Ayrıca ilgili fotoğraflar detaylandırılarak ilgili instagram sayfalarındaki temalar belirlenmek istenmiştir.

Rize ilindeki konaklama işletmecilerinin sosyal medya kullanımına yönelik düşüncelerini ve sosyal medya kullanımının oda taleplerini etkileyip etkilemediğine dair düşüncelerini ortaya çıkarmak için 20.05.2019 tarihinde telefon aracılığıyla görüşmeler yapılmıştır. Görüşmeler sosyal medya hesabı olan otellerin temsilcileri ile yapılmış olup, görüşmeler sırasında elde edilen veriler not alınmış ve sonrasında içerik analizine tabii tutulmuştur. 


\section{Bulgular}

Rize ilindeki konaklama işletmelerinin sosyal medya kullanım durumları, sosyal medya kullanımına yönelik düşünceleri ve sosyal medya kullanımının oda taleplerini etkileyip etkilemediği araştırılmıştır. Araştırmanın bu bölümünde, elde edilen bulgulara yer verilmiştir.

Araştırmada yer alan Rize'de faaliyet gösteren Kültür ve Turizm Bakanlığı İşletme Belgeli tesislerin web sayfalarına sahip olma durumları, bu sayfalarda instagram hesaplarına yer vermeleri ve özel açılmış instagram hesaplarının bilgileri Tablo 3'te yer almaktadır.

Tablo 3'e göre Rize'de bulunan 13 adet Kültür ve Turizm Bakanlığ İşletme Belgeli tesisin 12 tanesinin web sayfasına sahip olduğu, bu tesislerden 4 tanesinin web sayfalarında instagram hesabı sek- melerine yer verdikleri, 5 tanesinin de web sayfalarında instagram sekmelerine yer vermemelerine rağmen instagram hesabına sahip oldukları belirlenmiştir. $\mathrm{Bu}$ nedenle bu araştırmada, toplam 9 adet konaklama işletmesinin instagram sayfası incelemeye tabi tutulmuştur. İlgili konaklama işletmelerinin instagram hesaplarına ilişkin detaylı bilgilere Tablo 4'te yer verilmiştir.

Tablo 4'e göre konaklama işletmeleri instagramda ortalama 176 fotoğraf paylaşmıştır. En fazla paylaşımı X7 kodlu konaklama tesisi gerçekleştirirken, en az paylaşımı X4 kodlu konaklama tesisi gerçekleştirmiştir. Bunların dışında X1 (253 fotoğraf), X2 (197 fotoğraf), X5 (44 fotoğraf), X6 (75 fotoğraf), X8 (285 fotoğraf), X11 (22 fotoğraf) ve X12 (126 fotoğraf)'nin fotoğraflar paylaştığ1 görülmektedir.

Tablo 3. Rize'de faaliyet gösteren Kültür ve Turizm Bakanlığı İşletme Belgeli tesislerin web sayfaları ve İnstagram sayfalarına ilişkin bilgiler

\begin{tabular}{|c|c|c|c|c|c|}
\hline $\begin{array}{l}\text { Sira } \\
\text { No }\end{array}$ & Tesisin adı & Sinıfi & $\begin{array}{c}\text { Web sayfas } 1 \\
\text { Sahiplik durumu }\end{array}$ & $\begin{array}{l}\text { Web sayfasında instagram } \\
\text { hesabı yer alıyor mu? }\end{array}$ & $\begin{array}{l}\text { Özel açılmış instagram } \\
\text { hesabına sahip mi? }\end{array}$ \\
\hline 1 & $\mathrm{X} 1$ & $* * * * *$ & $\checkmark$ & $\checkmark$ & $\leftarrow$ \\
\hline 2 & $\mathrm{X} 2$ & $* * * * *$ & $\checkmark$ & $\checkmark$ & $\leftarrow$ \\
\hline 3 & $\mathrm{X} 3$ & $* * *$ & $\checkmark$ & Almiyor & Değil \\
\hline 4 & $\mathrm{X} 4$ & $* * *$ & $\checkmark$ & Almiyor & $\checkmark$ \\
\hline 5 & $\mathrm{X} 5$ & $* * *$ & $\checkmark$ & Almiyor & $\checkmark$ \\
\hline 6 & $\mathrm{X} 6$ & $* * *$ & $\checkmark$ & $\checkmark$ & $\leftarrow$ \\
\hline 7 & $\mathrm{X} 7$ & **** & $\checkmark$ & Almiyor & $\checkmark$ \\
\hline 8 & $\mathrm{X} 8$ & $* * *$ & $\checkmark$ & Almiyor & $\checkmark$ \\
\hline 9 & $\mathrm{X} 9$ & ** & $\checkmark$ & Almiyor & Değil \\
\hline 10 & $\mathrm{X} 10$ & $* *$ & Sahip Değil & Almiyor & Değil \\
\hline 11 & $\mathrm{X} 11$ & ** & $\checkmark$ & Almiyor & $\checkmark$ \\
\hline 12 & $\mathrm{X} 12$ & Özel & $\checkmark$ & $\checkmark$ & $\leftarrow$ \\
\hline 13 & $\mathrm{X} 13$ & Butik Otel & $\checkmark$ & Almıyor & Değil \\
\hline
\end{tabular}

Rize'de bulunan 13 adet Kültür ve Turizm Bakanlığı İşletme Belgeli konaklama tesisinin ortalama takipçi sayısı 4003 kişi iken takip ettikleri ortalama kişi sayısı 543,8'dir. Tablo 4'e göre takipçi sayisı en fazla olan konaklama tesisi X7 kodlu, en az takipçi sayısına sahip konaklama tesisi ise X4 kodlu işletmedir. Nitekim konaklama tesislerinin takipçileri ile etkileşimi incelendiğinde en çok beğeni aldıkları ve beğeniye oranla düşük seviyede yorum yaptıkları görülmektedir. Ayrıca beğeni ve yorum sayılarının takipçi sayısına göre değiştiği görülmektedir. Hazarhun ve Devrim Yilmaz
(2018), Bayram ve diğerleri (2016) araştırmalarında benzer sonuçlara ulaştıklarını belirtmişlerdir.

Araştırmada yer alan konaklama işletmelerinin instagram sayfalarında yer alan en son paylaştıkları fotoğraftan itibaren 15 fotoğraf geriye doğru analiz edilmiştir. Tablo 5'teki analiz sonuçlarına göre konaklama tesislerinin paylaştıkları fotoğrafların beğeni ve yorum sayıları, bu verilerle birlikte kapsadıkları içeriklere ilişkin temalar detaylı bir şekilde verilmiştir. 
Tablo 4. Rize'deki Kültür ve Turizm Bakanlığı İşletme Belgeli Tesislerin İnstagramdaki profillerine ilişkin tanımlayıcı bilgiler

\begin{tabular}{|c|c|c|c|c|c|c|}
\hline & Tesisin ad1 & Takipçi sayıs1 & $\begin{array}{c}\text { Takip edilen } \\
\text { say1S1 }\end{array}$ & $\begin{array}{c}\text { Gönderi sa- } \\
\text { y1S1 }\end{array}$ & $\begin{array}{c}\text { Ortalama yo- } \\
\text { rum say1S1* }\end{array}$ & $\begin{array}{c}\text { Ortalama be- } \\
\text { geni say1S1* }\end{array}$ \\
\hline 1 & $\mathrm{X} 1$ & 1214 & 74 & 253 & 0,70 & 40,7 \\
\hline 2 & $\mathrm{X} 2$ & 2660 & 282 & 197 & 2,40 & 100,2 \\
\hline 3 & $\mathrm{X} 4$ (7 Fotoğraf) & 47 & 87 & 7 & 0 & 5 \\
\hline 4 & $\mathrm{X} 5$ & 457 & 1037 & 44 & 0.06 & 17.3 \\
\hline 5 & $\mathrm{X} 6$ & 1008 & 0 & 75 & 0,26 & 38,8 \\
\hline 6 & $\mathrm{X} 7$ & 28000 & 1 & 581 & 3,93 & 713,8 \\
\hline 7 & $\mathrm{X} 8$ & 1462 & 2859 & 285 & 0,60 & 27,2 \\
\hline 8 & $\mathrm{X} 11$ & 85 & 0 & 22 & 1,13 & 37,5 \\
\hline 9 & $\mathrm{X} 12$ & 1100 & 555 & 126 & 2,53 & 191,2 \\
\hline & Ortalama & 4003 & 543,8 & 176 & 1,29 & 130,1 \\
\hline
\end{tabular}

*15 fotoğrafa ilişkin ortalama yorum ve beğeni sayısını ifade etmektedir.

Tablo 5'e göre 127 adet fotoğrafin incelenmesi sonucu 8 farklı tema oluşturulmuştur. Bu temalar (Tablo 6) "iç mekan, dış mekan, tebrik / özel gün, yiyecek-içecek, ziyaretçi, reklam / tanıtım, sosyal sorumluluk, destinasyon çekiciliği ve personel" olarak belirlenmiştir. X4 kodlu konaklama tesisi toplamda 15 adet fotoğraf paylaşmamasına rağmen araştırmadan çıkarılmamıştır. Paylaşılan fotoğrafların ortaya çıkarılan temalar üzerinde etkili olmaması dahil edilme sebebi olarak araştırmac1lar tarafindan kabul edilmiştir.

Hazarhun ve Devrim Yılmaz (2018)'ın araştırmalarında 10 adet tema ve Bayram ve diğerlerinin (2016)'nin araștırmalarında 11 adet tema belirlemişlerdir. Nitekim bu araştırmada da ilgili araştırmalara benzer temalar elde edilmiştir (Tablo 6). Bu sebeple araştırma bulgularının daha önce yapılan araştırmalarla uyumlu olduğu ifade edilebilir.

Tablo 7'ye göre konaklama ișletmelerinin instagram sayfalarında en çok iç mekân temalı fotoğraf paylaştıkları görülmektedir. Toplam 127 adet fotoğraf içerisinde 24 adet iç mekân temalı fotoğraf olduğu belirlenmiştir. İç mekan temalı içerikler resepsiyon, oda, toplantı salonu, kapalı havuz, restoran, lobi gibi konaklama işletmesinin sahip olduğu iç mekan öğelerini içermektedir. İç mekân temalı fotoğrafların haricinde en çok ziyaretçi (23 fotoğraf) ve konaklama ișletmelerinin dıș mekân (20 fotoğraf) temalı fotoğraflarının da hesaplarından paylaşıldı̆̆ 1 belirlenmiştir. Bu bağlamda en çok paylaşılan fotoğraf temaları genel olarak değerlendirildiğinde konaklama tesislerinin sahip olduğu mekânsal olanaklar, yapının görüntüsü ve ziyaretçilerine yönelik paylaşımlara önem verdikleri ifade edilebilir. Bunun yanı sıra Tebrik / Özel gün (17 fotoğraf), yiyecek-içecek (9 fotoğraf), reklam / tanıtım (13 fotoğraf), Destinasyon çekiciliği (14 fotoğraf) ve personel (2 fotoğraf) adet temalı fotoğraf paylaşıldığı belirlenmiştir.

Tablo 5 ve Tablo 7'de göze çarpan en önemli verilerden birisi X7 kodlu konaklama tesisinin en fazla ziyaretçi temalı fotoğraf paylaştığı, toplam paylaşılan fotoğraf sayısının (581 fotoğraf) bütün işletmelerden fazla olduğu (Tablo 4) ortalama paylaşılan fotoğraf sayısını önemli derecede etkilediği ve en fazla takipçi sayısına (28000) sahip olduğu belirlenmiştir. Bu bağlamda konaklama tesislerinin instagram hesaplarında fotoğraf paylaş1mının fazla olması, konaklama tesisi içerisindeki ziyaretçi temalı fotoğrafların paylaşımına önem verilmesi gibi unsurların takipçi sayısı üzerinde etkili olduğu, ayrıca sosyal medyada ön planda yer alma konusundaki önemini de ortaya çıkardığı ifade edilebilir. 


\begin{tabular}{|c|c|c|c|c|c|c|c|c|c|}
\hline & 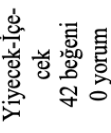 & 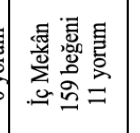 & & 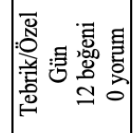 & 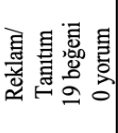 & 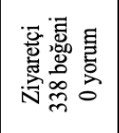 & 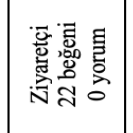 & 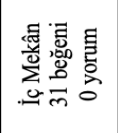 & 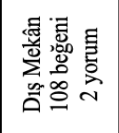 \\
\hline & & 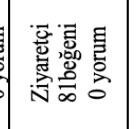 & & 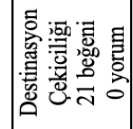 & 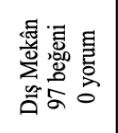 & 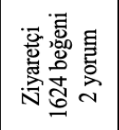 & 总 & 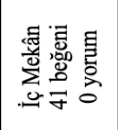 & 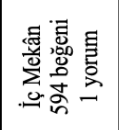 \\
\hline & & 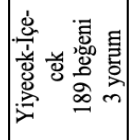 & & 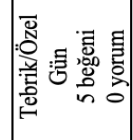 & 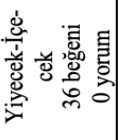 & 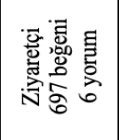 & 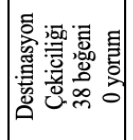 & 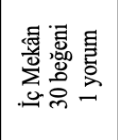 & 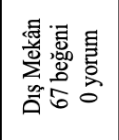 \\
\hline & & 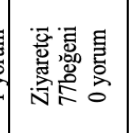 & & 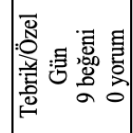 & 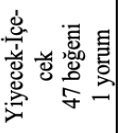 & 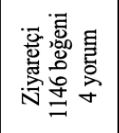 & 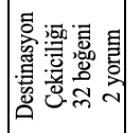 & 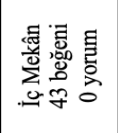 & 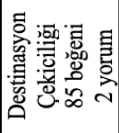 \\
\hline & & 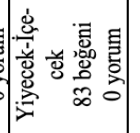 & & 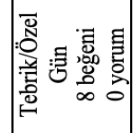 & 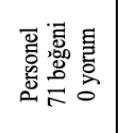 & 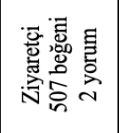 & 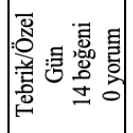 & 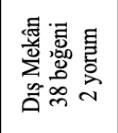 & 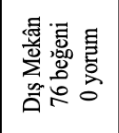 \\
\hline & & 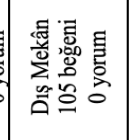 & & 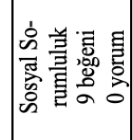 & 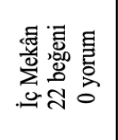 & 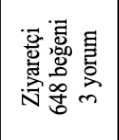 & 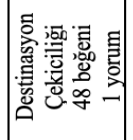 & 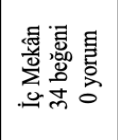 & 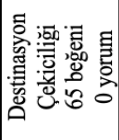 \\
\hline & 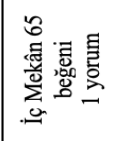 & 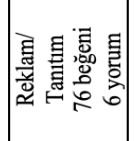 & & 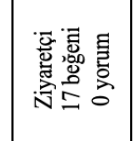 & 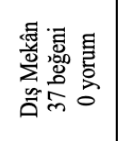 & 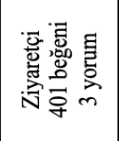 & 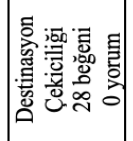 & 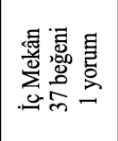 & 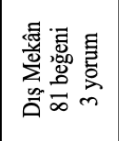 \\
\hline & 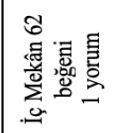 & 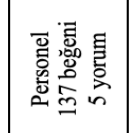 & & 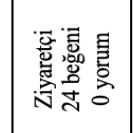 & 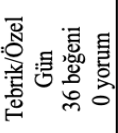 & 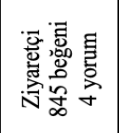 & 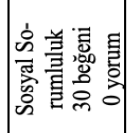 & 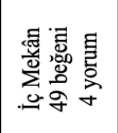 & 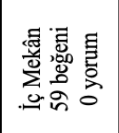 \\
\hline & 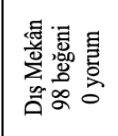 & 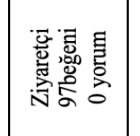 & 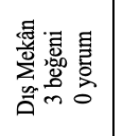 & 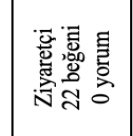 & 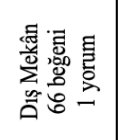 & 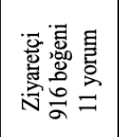 & 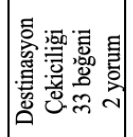 & 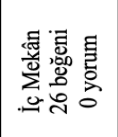 & 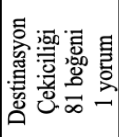 \\
\hline & & 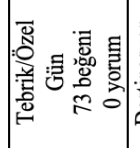 & 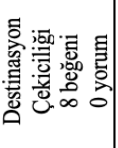 & 要 & 递然 & 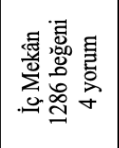 & 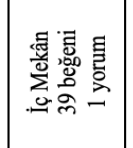 & 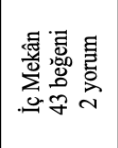 & 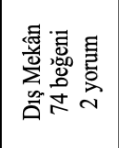 \\
\hline & 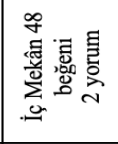 & 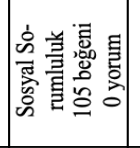 & 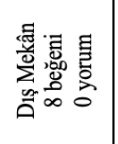 & 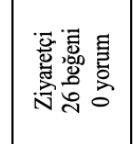 & 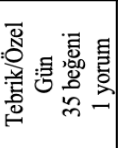 & 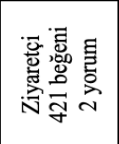 & 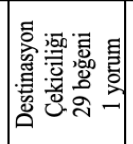 & 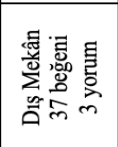 & 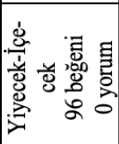 \\
\hline & 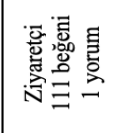 & 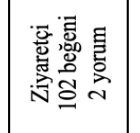 & 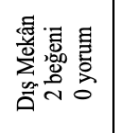 & 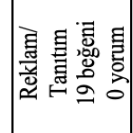 & 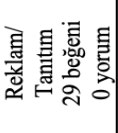 & 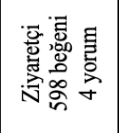 & 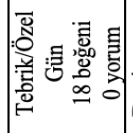 & 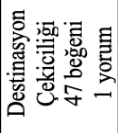 & 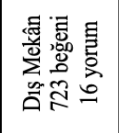 \\
\hline & 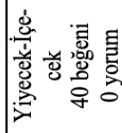 & 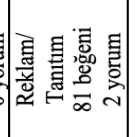 & 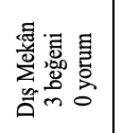 & 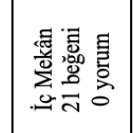 & 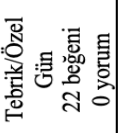 & 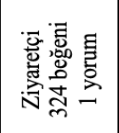 & 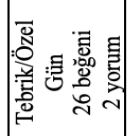 & 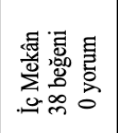 & 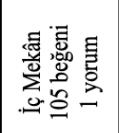 \\
\hline & Fo & 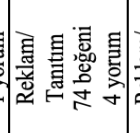 & 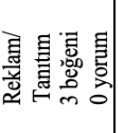 & 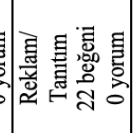 & 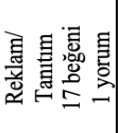 & 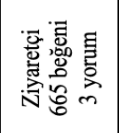 & 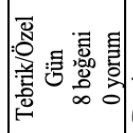 & 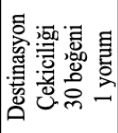 & 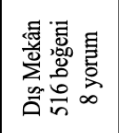 \\
\hline & 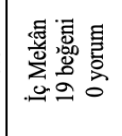 & 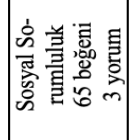 & 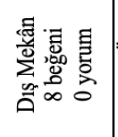 & 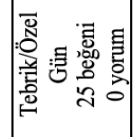 & 总 & 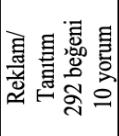 & 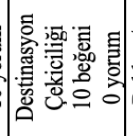 & 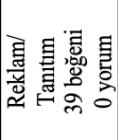 & 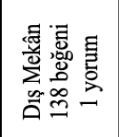 \\
\hline & $\bar{x}$ & $\tilde{x}$ & \pm & $\ddot{x}$ & $\ddot{x}$ & $\bar{x}$ & $\infty$ & $\overline{\bar{x}}$ & \\
\hline
\end{tabular}


Tablo 6. Rize'deki Kültür ve Turizm Bakanlığı İşletme Belgeli Tesislerin İnstagramda paylaştıkları fotoğraflara göre oluşturulan temaların ayrıntılı içerikleri

\begin{tabular}{|l|l|}
\hline \multicolumn{1}{|c|}{ Tema } & \multicolumn{1}{c|}{ İçerik } \\
\hline İç Mekân & Resepsiyon, oda, toplantı salonu, kapalı havuz, restoran, lobi vb. fotoğraflar. \\
\hline Dış Mekân & $\begin{array}{l}\text { Konaklama tesislerinin dışarıdan görünuş̧ü, bahçeleri, oda dış manzaraları vb. fo- } \\
\text { toğraflar. }\end{array}$ \\
\hline Tebrik / Özel Gün & $\begin{array}{l}\text { Ülke ile ilgili özel günler, herhangi bir kurumu veya kuruluşu tebrik, anma günleri, } \\
\text { kamu kurum ve kuruluşlarının yıl dönümleri, bayramlar vb. fotoğraflar. }\end{array}$ \\
\hline Yiyecek-İ̧ecek & Kahvaltı, yöresel yemek, meyve vb. fotoğraflar. \\
\hline Ziyaretçi & $\begin{array}{l}\text { Konaklama tesisinin herhangi bir bölümünde misafirlerin yer aldığı fotoğraflar, } \\
\text { kamu kurum yöneticileri ziyaret fotoğrafları. }\end{array}$ \\
\hline Reklam / Tanıtım & $\begin{array}{l}\text { Konaklama tesisinin özelliklerini barındıran ve reklam afişi olarak kullanılan fotoğ- } \\
\text { raflar, Rize'de gerçekleştirilen festival tanıtımları. }\end{array}$ \\
\hline Sosyal Sorumluluk & $\begin{array}{l}\text { Engelli bireyler için özel paylaşımlar ve etkinlik fotoğrafları, kadına şiddete karşı } \\
\text { tepki amaçlı fotoğraflar. }\end{array}$ \\
\hline Destinasyon Çekiciliği & $\begin{array}{l}\text { Ayder Yaylası, çay tarlaları, deniz, orman ve dağ manzaraları, yayla manzaraları } \\
\text { fotoğrafları. }\end{array}$ \\
\hline Personel & Konaklama tesisi iş görenleri fotoğrafları \\
\hline
\end{tabular}

Tablo 7. Rize'deki Kültür ve Turizm Bakanlığı İşletme Belgeli Tesislerin İnstagramda paylaştıkları fotoğraflara göre oluşturulan temalar ile ilgili paylaşım sayıları

\begin{tabular}{|c|c|c|c|c|c|c|c|c|c|c|}
\hline Tesisin adı & $\begin{array}{l}\text { İç } \\
\text { mekân }\end{array}$ & $\begin{array}{l}\text { Diş } \\
\text { mekân }\end{array}$ & $\begin{array}{c}\text { Tebrik / } \\
\text { özel gün }\end{array}$ & $\begin{array}{c}\text { Yiyecek } \\
\text { içecek }\end{array}$ & -Ziyaretçi & \begin{tabular}{|c|} 
Reklam / \\
tanitım
\end{tabular} & $\begin{array}{c}\text { Sosyal } \\
\text { sorumlu- } \\
\text { luk }\end{array}$ & $\begin{array}{c}\text { Desti- } \\
\text { nasyon } \\
\text { çekiciliği }\end{array}$ & Personel & Toplam \\
\hline $\mathrm{X} 1$ & 6 & 1 & 2 & 4 & 1 & 1 & - & - & - & 15 \\
\hline $\mathrm{X} 2$ & 1 & 1 & 1 & 2 & 4 & 3 & 2 & - & 1 & 15 \\
\hline X4 (7 Foto) & - & 5 & - & - & - & 1 & - & 1 & - & 7 \\
\hline $\mathrm{X} 5$ & 1 & - & 5 & - & 4 & 2 & 2 & 1 & - & 15 \\
\hline X6 & 1 & 3 & 4 & 2 & - & 4 & - & - & 1 & 15 \\
\hline $\mathrm{X} 7$ & 1 & - & - & - & 13 & 1 & - & - & - & 15 \\
\hline $\mathrm{X} 8$ & 1 & - & 5 & - & 1 & - & 1 & 7 & - & 15 \\
\hline $\mathrm{X} 11$ & 10 & 2 & - & - & - & 1 & - & 2 & - & 15 \\
\hline $\mathrm{X} 12$ & 3 & 8 & - & 1 & - & - & - & 3 & - & 15 \\
\hline Toplam & 24 & 20 & 17 & 9 & 23 & 13 & 5 & 14 & 2 & \\
\hline
\end{tabular}

“_“ ifadesi ilgili temada paylaşım yapılmadığını göstermektedir.

Araştırmanın ikinci kısmında Rize ilindeki konaklama işletmesi temsilcilerinin sosyal medya kullanımına yönelik düşüncelerini ve sosyal medya kullanımının otele olan taleplerini etkileyip etkilemediğine dair düşüncelerini ortaya çıkarmak için 20.05.2019 tarihinde telefon aracilığıyla görüşmeler yapılmıştır. Görüşmeler sırasında elde edilen veriler not alınmış ve sonrasında içerik analizine tabii tutulmuştur.

Rize'de bulunan 13 adet Kültür ve Turizm Bakanlığ İşletme Belgeli tesisin 12 tanesinin web sayfasına sahip olduğu, bu tesislerden 4 tanesinin web sayfalarında instagram hesabı sekmelerine yer verdikleri, 5 tanesinin de web sayfalarında instagram sekmelerine yer vermemelerine rağmen instagram hesabına sahip oldukları daha önce belirtilmişti. Buradan hareketle, sosyal medya hesabı olan otellerin temsilcilerine sosyal medya kullanımına yönelik ve sosyal medya kullanımının otel talebini etkileyip etkilemediğine dair görüşleri sorulmuştur. 9 işletme temsilcisinden (X1, X2, X4, X5, X6, X7, X8, X11, $\mathrm{X} 12$ ) sadece bir tanesi (X5) görüşmeyi kabul etmemiştir. Sosyal medya hesab1 yani instagram hesab1 olan otellerin temsilcilerine öncelikle sosyal medya kullanımına yönelik görüşleri sorulmuş. Sonrasında sosyal medya kullanımının işletmelere sağlayacağı avantaj ve dezavantajların neler olabileceği sorulmuştur. Son olarak işletme temsilcilerine otellerine ait instagram hesaplarının olmasının otel doluluk oranlarını nasıl etkilediği sorulmuştur. 
Instagram hesabı olan ve görüşmeyi kabul eden 8 otel temsilcisinden elde edilen veriler sonucunda işletmecilerin hepsinin sosyal medya kullanımına dair olumlu görüşlere sahip olduğu görülmektedir. $\mathrm{Bu}$ işletme temsilcileri, sosyal medya kullanımının işletmelerine olumlu yönde katkı sunduğunu ve birçok avantaj sağladığını belirtmiştir. Katılımcılar ayrıca sosyal medyanın avantaj sağladığını bilmelerine karşın instagramı etkin bir şekilde kullanmayı başaramadıklarını ifade etmişlerdir. Katılımcıların sosyal medya kullanımına yönelik bazı ifadeleri Tablo 8'de verilmiştir.

Instagram hesabı olan ve görüşmeyi kabul eden 8 otel temsilcisine ayrica, otellerine ait instagram hesaplarının olmasının otel doluluk oranlarını na- sil etkilediği sorulmuştur. Elde edilen veriler sonucunda işletmecilerin 4 tanesi instagram hesab1nın olmasının doluluklara olumlu yönde etki ettiğini belirtmiştir. Instagramın otellerin doluluğuna etki oranı otelden otele değişmektedir. Bazı işletmeciler ciddi anlamda otel doluluklarına instagram hesabının olmasının etkisi olduğunu belirtirken, bazı işletmeciler nadir de olsa instagram hesabından satış yaptıklarını belirtmiştir. Kalan 4 otel işletmecisinden de 3'ü instagram üzerinden satış yapan işletmecileri duyduklarını ifade etmiştir.

Tablo 8. Instagram hesabı olan işletme temsilcilerinin sosyal medya (Instagram) kullanımına yönelik görüşleri

\begin{tabular}{|c|c|}
\hline İşletme & Instagram Hesabı Olan İşletme Temsilcilerinin Sosyal Medya Kullanımına Yönelik Görüşleri \\
\hline $\mathrm{X} 1$ & $\begin{array}{l}\text { Gelecekte satısların kesinlikle tamamen sosyal medyadan olacă̆ düşüncesindeyim. Turistler sosyal } \\
\text { medya üzerinden görmediği yere gitmek istemiyor. Bu konuda biraz geç kaldık ama çalışmalara de- } \\
\text { vam ediyoruz. Profesyonel yardım almayl düşünüyoruz. }\end{array}$ \\
\hline $\mathrm{X} 2$ & $\begin{array}{l}\text { Sosyal medyanın tanttım să̆lama konusunda avantaj sağladı̆̆ını düşünüyoruz. Tabi misafirler bizim } \\
\text { eksikliklerimizi de paylaşabiliyorlar. O da ayrı konu.. }\end{array}$ \\
\hline $\mathrm{X} 4$ & $\begin{array}{l}\text { Instagram üzerinden satıs yapanları duyuyoruz. Daha önce üzerine düssek daha iyi sonuçlar alabi- } \\
\text { lirdik. Bu sayfa üzerinden kazancımı olduğunun farkındayım. }\end{array}$ \\
\hline $\mathrm{X} 6$ & $\begin{array}{l}\text { Instagramın reklam, tanıtım, müşteriye ulaşma, doğal güzelliklerin tanıtımı gibi avantajları olmak- } \\
\text { tadır. }\end{array}$ \\
\hline $\mathrm{X} 7$ & $\begin{array}{l}\text { Instagram ile artık video ve fotoğraflar dünya üzerinde çok hizl yayllyyor. Reklam ve tanıtım için en } \\
\text { güvenilir araç, ayrıca ziyaretçi tavsiyeleri önemli oluyor ve güvenirlilik yaratıyor. Ayrıca instagram } \\
\text { aracıllığyla müşsteri sorularına hemen yant verebiliyoruz. }\end{array}$ \\
\hline $\mathrm{X} 8$ & Instagramın reklam yapma avantajı var. Insanlar artık etkin bir șekilde instagram kullanıyor. \\
\hline $\mathrm{X} 11$ & $\begin{array}{l}\text { Instagramin birçok olumlu yönü var. Insanlar artık instagram aracıllğıyla satıs yapmaya başladl. } \\
\text { Ben de daha fazla üzerine düsssem belki daha iyi olurdu. Çok şükür şimdilik çok da sikntımız yok. }\end{array}$ \\
\hline $\mathrm{X} 12$ & $\begin{array}{l}\text { Her şey teknoloji içinden çıklyor. Mesela buralar kimse bilmezken instagram üzerinde fotoğrafi gö- } \\
\text { rüp geliyorlar. Avantajları var dolayısı ile ben de emek harcyyorum. }\end{array}$ \\
\hline
\end{tabular}

Geriye kalan bir otel işletmecisi ise zaten otel doluluk oranlarının çok iyi olduğunu dolayısı ile instagram kullanmanın ve bu kanalla müşteriye ulaşmaya gerek kalmadığını ifade etmiştir. Instagram hesabı olan otellerin temsilcilerinin instagram kullanımının otel doluluk oranlarına etkisine yönelik belirttikleri bazı ifadeler Tablo 9'da verilmiştir.

Genel olarak bir değerlendirme yapıldığında, Rize ilinde araştırma kapsamındaki otel temsilcilerinin neredeyse tamamı instagram hesabı kullanımının otel doluluk oranlarına katkısı olduğunu düşünmektedir. Her ne kadar bazı otellerdeki instagram hesabının kullanımının doluluklara direkt etkisi olmasa da diğer işletme temsilcilerinden olumlu etkiyi duymuşlardır. İşletmecilerin instagram gibi sosyal medya hesaplarının önemini yeni yeni keşfettikleri, dolayısı ile bu platformu etkin şekilde kullanmaya yeni başladıkları söylenebilir. 
Tablo 9. Instagram hesabı olan otel temsilcilerinin Instagram kullanımının otel doluluk oranına etkisine yönelik görüşleri

\begin{tabular}{|c|c|}
\hline İşletme & $\begin{array}{l}\text { Instagram Hesabı Olan Otel Temsilcilerinin Instagram Kullanımının Otel Doluluk Oranına Etkisine Yönelik } \\
\text { Görüşleri }\end{array}$ \\
\hline $\mathrm{X} 1$ & $\begin{array}{l}\text { Sosyal medyanın önemi her geçen gün turizmde arttyor. Bu platformlardan insanlara ulaşmak lazım. Kesin- } \\
\text { likle bir fotoğrafin bir yer için önemli etkisi var. Bu konuda satış yapanlar çoğald. Şu an bizim için çok etkili } \\
\text { satıs yok. Takipçimiz az. }\end{array}$ \\
\hline $\mathrm{X} 2$ & $\begin{array}{l}\text { Instagram hesabımız var. Açı söylemek gerekirse doluluk üzerinde pek etkisi yok. Fakat arada görüp tercih } \\
\text { edenler, ulaşanlar nadir de olsa oluyor. }\end{array}$ \\
\hline $\mathrm{X} 4$ & $\begin{array}{l}\text { Web sayfamızı sadece iletişim için aktif tutuyoruz. Otelimiz gerekli doluluk oranlarına ulaşıyor. Bu yüzden çok } \\
\text { fazla instagrama önem vermedik. }\end{array}$ \\
\hline $\mathrm{X} 6$ & 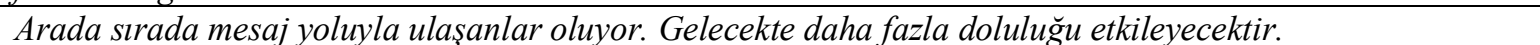 \\
\hline X7 & $\begin{array}{l}\text { Instagram bizim sosyal medya araçlarından en fazla kullanilanıdır. Çok fazla insana ulaşabiliyoruz. Onlara } \\
\text { issletmemizi ve olanaklarımızı tanitabiliyoruz. Unlü isimleri ağırlyyoruz. Bizim reklamımızı da yapabiliyorlar. } \\
\text { Otel doluluğumuz üzerinde instagram etkili oluyor. }\end{array}$ \\
\hline $\mathrm{X} 8$ & $\% 10$ gibi bir c \\
\hline $\mathrm{X} 11$ & ipanları duyuyoruz. \\
\hline X12 & $\begin{array}{l}\text { Instagram hesabının olmasının talebi etkileyip etkilemediği konusunda bir fikrim yok. Biz de kendimizi tekno- } \\
\text { lojiye aktarmaya çalışıoruz. Instagramdan oda satısıs yapanları duydum. Ben daha yapmadım. Fotoğraflart- } \\
\text { mız beğeniliyor, gelecekte katkısı olacağını düsünüyorum. }\end{array}$ \\
\hline
\end{tabular}

\section{Sonuç ve değerlendirme}

Bu çalışmada, Türkiye'nin Doğu Karadeniz Bölgesinde önemli bir turizm destinasyonu olan Rize ilindeki konaklama işletmelerinin sosyal medya kullanım durumları ve otel doluluk oranlarına etkisi araştırılmıştır. Bu bağlamda öncelikle 13 adet Kültür ve Turizm Bakanlığı İşletme Belgeli konaklama tesisinin web sayfaları ardından instagram hesapları incelenmiştir. Konaklama tesislerin instagramdaki profilleri incelenmiş ve tesislerin instagramda paylaştıkları fotoğrafların beğeni ve yorum sayıları, kapsadıkları içeriklere ilişkin temalar ortaya çıkarılmıştır. Çalışmanın ikinci kısmında instagram hesabı olan konaklama işletmesi temsilcileri ile sosyal medya kullanımına yönelik ve sosyal medya kullanımının talebi etkileyip etkilemediğine dair düşüncelerini ortaya çıkarmak için görüşmeler yapılmıştır.

Bu çalışmada Rize'de faaliyet gösteren 9 adet konaklama işletmesinin instagram sayfaları incelenmiştir. Araştırma kapsamındaki konaklama işletmelerinin instagram sayfalarında ortalama 176 fotoğraf paylaşı1dığı, ortalama takipçi sayılarının 4003 kişi, takip ettikleri ortalama kişi sayılarının da 543,8 olduğu belirlenmiştir. Konaklama tesislerinin takipçileri ile etkileşimleri incelendiğinde paylaştıkları fotoğraflar için en çok, beğeni aldıkları ve beğeniye oranla düşük seviyede yorum yapıldığg görülmüştür. Ayrıca beğeni ve yorum sayılarının takipçi sayısına göre değişim gösterdiği belirlenmiştir.
Çalışma kapsamında yer alan konaklama işletmelerinin instagram sayfalarındaki fotoğrafların incelenmesi sonucu sekiz farklı tema oluşturulmuştur. Bu temalar "iç mekan, dış mekan, tebrik / özel gün, yiyecek-içecek, ziyaretçi, reklam / tanıtım, sosyal sorumluluk, destinasyon çekiciliği ve personel" olarak ifade edilmiştir. Konaklama işletmelerinin instagram sayfalarında en çok iç mekan temalı fotoğraf paylaştıkları, iç mekan temalı içeriklerin "resepsiyon, işletme odaları, toplantı salonu, kapalı havuz, restoran, lobi" gibi işletmelerin sahip olduğu iç mekan öğelerini temsil ettiği görülmüsşür. Konaklama tesislerinin instagram hesaplarında fotoğraf paylaşımının çok olması, konaklama tesisi içerisindeki ziyaretçi temalı fotoğrafların paylaşımına daha fazla önem verilmesi gibi unsurların takipçi sayısı üzerinde etkili olduğu görülmüştür. $\mathrm{Bu}$ da, sosyal medyada ön planda yer almamanın ne kadar önemli olduğunu ortaya çıkarmıştır. Bu bağlamda araştırma sonuçları alan yazında yapılan çalışmaları destekler niteliktedir (Lee, 2012; Yahya, Azizam ve Mazlan, 2014).

Çalışmanın en önemli sonuçlarından bir tanesi de otele ait bir instagram hesabının kullanımının otel doluluk oranlarını arttırdığını ve önemli ölçüde etkilediğini belirten işletmelerin (X7 ve X8), takipçi sayılarının ve paylaşım sayılarının diğer otel işletmelerinin instagram hesaplarındaki paylaşım ve takipçi sayılarından daha fazla olmasidır. Ayrica instagramın otel doluluğunda önemli etkisi olduğunu belirten ve en fazla takipçi ve gönderiye sahip olan işletmenin (X7) 
paylaşımlarında ağırlıklı olarak otele gelen müşterilerin fotoğraflarının olması da diğer dikkat çekici bir sonuçtur. Kısacası, konaklama tesislerinin instagram hesaplarında fotoğraf paylaşımının çok olması, konaklama tesisi içerisindeki ziyaretçi temalı fotoğrafların paylaşımına daha fazla önem verilmesi gibi unsurların takipçi sayısı üzerinde etkili olduğu, bunun da otele olan talebe yansıdığı sonucu çıkmaktadır. Yapılan çalışmalar, turistlerin diğer turistlerin yaptı̆̆ 1 sosyal medya paylaşımlarından etkilendiğini ortaya koymuştu (Barreda ve Bilgihan, 2013), bu çalışmada, otellerin ziyaretçi temalı fotoğraf paylaşmalarının da dolaylı yoldan konaklama işletmesine olan talebi etkilediği görülmüştür.

Teknolojik gelişmelerin turizm sektöründe hizmet veren konaklama işletmelerini ve turizm hareketine katılan bireyleri etkilediği aşikârdır. Bu gelişmelerin gün geçtikçe hızlandığı ve turizm sektörünü de aynı hızla içine aldığı gözle görülmektedir. Nitekim turizm sektöründeki reklam pazarlama faaliyetleri gibi etkenler de doğrudan veya dolaylı olarak teknoloji ile bir araya gelmektedir. Bu bağlamda turizm sektörünün de sosyal medya ile entegre olmaya başladığı, yeni gelişmelerin sektör ve bireylerle paylaşıldığ 1 , bu durumun öneminin işletme yöneticileri tarafindan hızla kavrandığı söylenebilir. Doğaldır ki, bu çalışmanın bir takım kısıtlılıkları ve eksik yanları vardır. Bu araştırma Rize ilinde, 13 adet Kültür ve Turizm Bakanlığı İşletme Belgeli konaklama tesisini kapsamaktadır. Çalışmada otele ait bir instagram hesabının kullanımının talebi etkileme durumu işletme yöneticileri ve işletme sahipleri ile görüşülerek belirlenmeye çalışılmıştır.

Konaklama işletmelerinin web sayfaları ve instagram sayfalarının detaylı değerlendirilmesi ve birçok etkenin ortaya çıkarılması ve bu bağlamda yapılan görüşmeler ile elde edilen instagram sayfa verileri arasında bağ kurulmaya çalışılmıştır. Bu bakımdan, çalışmanın alan yazındaki önemli bir boşluğu da kapattığı düşünülmektedir. Gelecekte benzer çalışmaların, özellikle daha farklı örneklem kitleleri ile yapılmasının yerinde olacağ1 ve bu çalışmanın yeni araştırmalara önemli bir altyapı oluşturacağı düşünülmektedir.

$\mathrm{Bu}$ araştırma Rize ilinde, 13 adet Kültür ve Turizm Bakanlığı İşletme Belgeli konaklama tesisini kapsamaktadır. Araştırmanın sonunda elde edilen sonuçlar, araştırma kapsamı doğrultusunda geçerlidir, dolayısı ile genellenemez. Farklı örneklemlerde benzer çalışmalar yapılarak instagram kullanımının talebi etkileyip etkilemediği değerlendirilmelidir.

\section{Kaynakça}

Al-Badi, A., \& Al-Qayoudhi, W. (2014). Adoption of social networks in business: Study of users and potential users in Oman. International Business \& Economics Research Journal, 13(2), 401-418.

Aluri, A. K. (2012). Does embedding social media channels in hotel websites influence travelers' satisfaction and purchase intentions? (Doctoral dissertation, Oklahoma State University).

Balomenou, N., \& Garrod, B. (2019). Photographs in tourism research: Prejudice, power, performance and participant-generated images. Tourism Management, 70, 201217.

Barreda, A., \& Bilgihan, A. (2013). An analysis of user-generated content for hotel experiences. Journal of Hospitality and Tourism Technology, 4(3), 263-280.

Barwise, P., \& Strong, C. (2002). Permission-based mobile advertising. Journal of interactive Marketing, 16(1), 1424.

Bayram, M., Bayram, Ü. \& Arıcı, S. (2016). Otel işletmeleri Instagram Paylaşımlarının Sosyal Medya Pazarlaması Kapsamında İçerik Analizi Yöntemi ile Değerlendirilmesi. Journal of Business Research 8(2) :427442.

Carr, N. K., \& Maier, S. P. (2013). Social media policies: Managing risks in a rapidly developing technological environment. Mustang Journal of Law and Legal Studies, 4, 87-106.

Chung, H. C., Chung, N., \& Nam, Y. (2017). A social network analysis of tourist movement patterns in blogs: Korean backpackers in Europe. Sustainability, 9(12), 2251.

Corbau, C., Benedetto, G., Congiatu, P. P., Simeoni, U., \& Carboni, D. (2019). Tourism analysis at Asinara Island (Italy): Carrying capacity and web evaluations in two pocket beaches. Ocean \& Coastal Management, 169, 27-36.

Deng, N., \& Li, X. R. (2018). Feeling a destination through the "right" photos: A machine learning model for DMOs' photo selection. Tourism Management, 65, 267278.

Diehl, K., Zauberman, G., \& Barasch, A. (2016). How taking photos increases enjoyment of experiences. Journal of personality and social psychology, 111(2), 119.

Di Pietro, L., Di Virgilio, F., \& Pantano, E. (2012). Social network for the choice of tourist destination: Attitude and behavioural intention. Journal of Hospitality and Tourism Technology, 3(1), 60-76. doi:10.1108/17579881211206543 
DiStaso, M. W., \& McCorkindale, T. (2012). Social media: Uses and opportunities in public relations. Global Media Journal, 5(2), 75.

Eren, R., \& Çelik, M. (2017). Çevrimiçi Gastronomi İmajı: Türkiye Restoranlarının Tripadvisor Yorumlarının İçerik Analizi. Turizm Akademik Dergisi, 4(2), 121-138.

Erkılıç E., Güçer, E., Pelit, E., \& Aytekin, E. (2016). Destinasyon Pazarlamasında Web Sayfalarının Rolü: Rize'deki Kamu Kurumlarının Web Siteleri Üzerine Bir İnceleme, II. Rize Turizm Sempozyumu, 4-6 Kasım, Rize.

Erkılıç E., Kılıç G., Pelit E., \& Kılıç İ., (2016). Çamlıhemşin'deki Çekiciliklere Yönelik Ziyaretçi Görüşlerinin Seyahat 2.0 Uygulamaları Üzerinden Değerlendirilmesi Tripadvisor.Com Örneği, I. Ulusal Alternatif Turizm Kongresi, Erzincan, Türkiye, 7-9 Nisan.

Erkılıç, E., \& Yıldırım, G. (2019). An Evaluation on Social Media Users' E-reviews of Food-Beverage Businesses: The Case of Rize, in Social Science I, Cahit Aslan, Özlem Aygoğmuş Ördem, Eds., Akademisyen Kitabevi.

Fesenmaier, D. R., Wöber, K. W., \& Werthner, H. (Eds.). (2006). Destination recommendation systems: Behavioral foundations and applications. CABI.

García-Palomares, J. C., Gutiérrez, J., \& Mínguez, C. (2015). Identification of tourist hot spots based on social networks: A comparative analysis of European metropolises using photo-sharing services and GIS. Applied Geography, 63, 408-417.

Gedikoglu, Z. A. (2018). Exploring Destination Image Themes on Twitter, Before, During, and After Terror Attacks in Paris: An Application of Agenda Setting Theory. Doctoral Dissertation Presented to the Graduate School of Clemson University.

Giglio, S., Bertacchini, F., Bilotta, E., \& Pantano, P. (2019). Using social media to identify tourism attractiveness in six Italian cities. Tourism Management, 72, 306-312.

Hazarhun, E. \& Devrim Y1lmaz, Ö. (2018). Afyonkarahisar'daki Termal Otellerin Sosyal Medya Kullanımı: Instagram Örneği, 19. Ulusal Turizm Kongresi, Sağlık Turizmi, 17-21 Ekim, Afyonkarahisar.

Iacovou, C. (2016). An analysis of social media marketing strategies and best practices of hospitality and tourism organizations, A Thesis of Degree of Doctor of Business Administration, Submitted to Northcentral University, Arizona

Janis, I. L. (1949). The Problem of Validating Content Analysis. H.D. Lasswell ve ark (eds), The Language of Politics: Studies in Quantitative Semantics, George Stewart. New York, pp. 55-82.

Jiang, K., Yin, H., Wang, P., \& Yu, N. (2013). Learning from contextual information of geo-tagged web photos to rank personalized tourism attractions. Neurocomputing, 119, 17-25.
Kennedy, L., Naaman, M., Ahern, S., Nair, R., \& Rattenbury, T. (2007). How flickr helps us make sense of the world: context and content in community-contributed media collections. In Proceedings of the 15th ACM international conference on Multimedia, 631-640.

Khoo-Lattimore, C., \& Prideaux, B. (2013). ZMET: A psychological approach to understanding unsustainable tourism mobility. Journal of Sustainable Tourism, 21(7), 1036-1048.

Kisilevich, S., Keim, D., \& Rokach, L. (2010). A novel approach to mining travel sequences using collections of geotagged photos. In Geospatial thinking (pp. 163-182). Springer, Berlin, Heidelberg.

Knackmuhs, E. (2011). But Does it Work? The Impact of Social Media Use on Interpretive Outcomes and Place Attachments at San Francisco Bay Area Parks, A Thesis for the Degree of Master of Science in Resource Interpretation, Presented to the Faculty of the Graduate School of Stephen F. Austin State University.

Knights, D., \& Willmott, H. (2007). Introducing organizational behaviour and management. Cengage Learning EMEA.

Kurashima, T., Iwata, T., Irie, G., \& Fujimura, K. (2013). Travel route recommendation using geotagged photos. Knowledge and information systems, 37(1), 37-60.

Lee Rosen, D. (2017). Mapping motivations for a Canadian leisure experience: impact of social media engagement, Doctoral dissertation of Royal Roads University Victoria, British Columbia, Canada.

Lee, P. M. (2002). Behavioral model of online purchasers in e-commerce environment [Electronic version]. Electronic Commerce Research, 2, 75-85.

Leung, X. Y. (2012). The marketing effectiveness of hotel Facebook pages: From perspectives of customers and messages. A dissertation submitted in partial fulfillment of the requirements for the Doctor of Philosophy in Hospitality Administration Peking University, Beijing, China.

Li, Q., Huang, Z. J., \& Christianson, K. (2016). Visual attention toward tourism photographs with text: An eyetracking study. Tourism Management, 54, 243-258.

Li, X. (2013). Multi-day and multi-stay travel planning using geo-tagged photos. In Proceedings of the second ACM SIGSPATIAL international workshop on crowdsourced and volunteered geographic information (pp. 1-8). ACM.

Ma, Y., Xiang, Z., Du, Q., \& Fan, W. (2018). Effects of userprovided photos on hotel review helpfulness: An analytical approach with deep leaning. International Journal of Hospitality Management, 71, 120-131.

Marek, N. E. (2015). Tourism in crisis: A qualitative content analysis of SeaWorld's Twitter response to backlash. Thesis Submitted to the department of Communication Eastern Michigan University. 
McCarthy, L., Stock, D., \& Verma, R. (2010). How travelers use online and social media channels to make hotelchoice decisions. Cornell Hospitality Report, 10 (18), 418.

McKay, L. (2010). The hospitality suite: hotels are finding a home away from home in social media, and boosting the customer experience in the process [Electronic version]. Customer Relationship Management, September 2010.

Moore, S. L. (2017). The Mediation of the Constructed Landscape: Photographs of North Central Indiana Subdivision. International Journal of the Image, 8(2).

Muckensturm, E. (2013). Using dialogic principles on Facebook: how the accommodation sector is communicating with its' consumers. A Thesis Presented to the Graduate School of Clemson University.

Nikjoo, A., \& Bakhshi, H. (2019). The presence of tourists and residents in shared travel photos. Tourism Management, 70, 89-98.

Nyakabwa, I. N. (2017). The role of selected social media platforms in travel to Bwindi Impenetrable National Park, Uganda. A Thesis of Degree Master of Science Parks, Recreation and Tourism Management, Presented to the Graduate School of Clemson University.

Okazaki, S., \& Taylor, C. R. (2013). Social media and international advertising: Theoretical challenges and future directions. International Marketing Review, 30(1), 5671.

Özdemir M., (2010). Nitel veri analizi: sosyal bilimlerde yöntembilim sorunsalı üzerine bir çalışma, Eskişehir Osmangazi Üniversitesi Sosyal Bilimler Dergisi, 11, 323343.

Rishi, M., \& Gaur, S. S. (2012). Emerging sales and marketing challenges in the global hospitality industry. Worldwide Hospitality and Tourism Themes, 4(2), 131-149.

Rize İl Kültür ve Turizm Müdürlüğü (2018).Tesisler ve Acentalar. https://rize.ktb.gov.tr/TR-234935/tesisler-veacentalar.html

Safko, L. (2013). The fusion marketing bible. New York, NY: McGraw Hill.

Shao, H., Zhang, Y., \& Li, W. (2017). Extraction and analysis of city's tourism districts based on social media data. Computers, Environment and Urban Systems, 65, 66-78.

Sheldon, P. J. (1997). Tourism information technology. Oxford: $\mathrm{CAB}$.

Smallwood, C. B., Beckley, L. E., \& Moore, S. A. (2012). An analysis of visitor movement patterns using travel networks in a large marine park, north-western Australia. Tourism Management, 33(3), 517-528.

Snavely, N., Seitz, S. M., \& Szeliski, R. (2008). Modeling the world from internet photo collections. International journal of computer vision, 80(2), 189-210.
Ukpabi, D. C., \& Karjaluoto, H. (2017). Consumers' acceptance of information and communications technology in tourism: A review. Telematics and Informatics, 34(5), 618-644.

Van House, N. A. (2011). Personal photography, digital technologies and the uses of the visual. Visual Studies, 26(2), 125-134.

Vu, H. Q., Li, G., Law, R., \& Ye, B. H. (2015). Exploring the travel behaviors of inbound tourists to Hong Kong using geotagged photos. Tourism Management, 46, 222232.

Weber, L. (2013). The social enterprise: Building a digitally driven business to gain competitive advantage. Journal of Digital \& Social Media Marketing, 1(1), 6-16.

Werthner, H., \& Klein, S. (1999). Information technology and tourism: A challenging relationship. Springer-Verlag Wien.

Xiang, Z. (2018). From digitization to the age of acceleration: On information technology and tourism. Tourism Management Perspectives, 25, 147-150.

Yahya, A. H., Azizam, A. A., \& Mazlan, D. B. (2014). The impact of electronic words of mouth (eWOM) to the brand determination of higher education in Malaysia: From the perspective of middle east's student. Journal of Mass Communication Journalism, 4, 1-4.

Yang, L., Wu, L., Liu, Y., \& Kang, C. (2017). Quantifying tourist behavior patterns by travel motifs and geo-tagged photos from Flickr. ISPRS International Journal of GeoInformation, 6(11), 345.

Yuan, Y., \& Medel, M. (2016). Characterizing international travel behavior from geotagged photos: A case study of flickr. PloS one, 11(5), e0154885.

Zeng, B. (2013). Social media in tourism. Journal of Tourism and Hospitality, 2(2), 1-2.

Zheng, Y. T., Zha, Z. J., \& Chua, T. S. (2012). Mining travel patterns from geotagged photos. ACM Transactions on Intelligent Systems and Technology (TIST), 3(3), 56. 


\section{Extended abstract in English}

Through the development of technology, widespread use of the Internet and smart phones, bilateral communication between consumers and consumers, consumers and businesses and other businesses has become possible. With the increasing information sharing in the tourism sector and the increasing role of social media on this issue, tourism enterprises have to be active in social media. In addition to traditional marketing methods, the importance given to social media marketing is increasing day by day. Thus, in this study, social media use cases of hotels in Rize province, which is one of Turkey's popular tourist attractions and its effect on hotel occupancy rates were examined.

The main problem of the research is as follows:

- What are the social media usage status of accommodation companies in Rize and what is the effect of using social media on hotel occupancy rates?

In this main research question, two sub-research questions are as follows:

- What are the thoughts of the managers of accommodation establishments in Rize about the use of social media?

- What is the level of interaction of the accommodation companies in Rize with the visitors in social media?

- What are the differences between sharing status of high interactive accommodation companies with low interactive accommodation companies?

- What is the demand for enterprises with high level of interaction compared to accommodation enterprises with low levels of interaction?

In this study, firstly web sites of accommodation companies in Rize were examined and then instagram accounts were examined. The reason for choosing instagram among different kinds of social media is that people give importance to photographic data (Balomenou and Garrod, 2019: 201) and that is one of the most important photo and video sharing platforms (Diehl et al., 2016). Afterwards, if any, shared photographs were analyzed through social media accounts and their interaction with visitors was evaluated. Then, the effects of social media usage of hotels with social media accounts on hotel occupancy were tried to be revealed. In this study qualitative research method was chosen and interview technique was used to collect data.
Profiles of the accommodation companies in the instagram were examined and the themes about likes and the comments of the photos they share in instagram, the contents of the shared photos were revealed. In the second part of the study, interviews were conducted with the representatives of the accommodation business who have an instagram account to reveal their opinions about the use of social media and whether the use of social media has affected the demand.

In Rize province, there are 13 accommodation companies licensed by Ministry of Culture and Tourism Ministry. In the first part of the study, web sites and instagram usage status of all companies were examined. In the second part of the study, hotel representatives who have an instagram account were interviewed. In this section, representatives of hotels that do not have an Instagram account have not been interviewed because this study investigates whether the use of the instagram account affects hotel occupancy rates.

As a result of examining the photographs in the instagram pages of the accommodation establishments included in the study, eight different themes were created. These themes are 'indoor, outdoor, greeting / special days, food \& beverage, visitor, advertisement/promotion, social responsibility, destination attractiveness and staff'. It is seen that accommodation establishments share mostly interior space photos on instagram pages and the interior theme represents the interior elements of the enterprises such as 'reception, hotel rooms, meeting room, indoor pool, restaurant, lobby'.

It was found that sharing of photos in the instagram accounts of the accommodation companies and emphasis on the sharing of visitor-themed photos within the accommodation companies' instagram account were effective on the number of followers. This has revealed how important it is to be interactive in social media.

One of the most important results of the study is that the use of an instagram account increases hotel occupancy rates and the hotel managers who express this (X7 and X8) have more followers and sharing in instagram than the other hotels. In addition, the hotel (X7), whose manager stated that instagram has a significant effect on hotel occupancy, and which have the most 
followers and sharing in instagram shares mostly visitors-themed photos. This is another remarkable result of the study.

In short, it is concluded that high number of photos sharing in the accommodation companies' instagram account, the emphasis on sharing visitor-themed photos in the accommodation companies' instagram account are very effective on the number of followers, and this increases the demand for the hotel.

It is obvious that technological developments affect the hospitality enterprises serving the tourism sector and the individuals who participate in the tourism movement. It is evident that these developments are increasing day by day and that the tourism sector have been affected at the same time. In this context, it can be said that the tourism sector is also integrated with social media, new developments are shared with the sector and individuals, and the importance of this situation is quickly understood by business managers. Naturally, this study has some limitations. In this research, 13 hotels licensed by Culture and Tourism Ministry in Rize included in the research and the impact of the use of a hotel's instagram account on the demand was determined by interviewing with business managers and business owners.

A detailed evaluation of web sites and instagram pages of accommodation businesses has been carried out and revealing many factors and linking the instagram page data obtained with the interviews conducted with the hotel managers has been tried to be done. In this respect, as there is a significant gap in the literature, this study is thought to be beneficial. It is believed that similar studies in the future can be done with different sample sizes and this study will constitute an important infrastructure for new researches. 